\title{
Role of Acute Phase Reactants: Study in Diabetic and Non Diabetic Patients Suffering from Sepsis in India
}

\author{
Waliza Ansar ${ }^{1^{*}}$ and Sheikh Hasan Habib \\ ${ }^{1}$ Assistant Professor, Undergraduate Department of Zoology, Behala College, Upen Banerjee Road, Parnasree, \\ Kolkata-700060, India \\ ${ }^{2}$ General Physician, Fleming Hospital, Kolkata-700046 and Ex-Senior Resident, Department of Anesthesiology, \\ K. P. C. Medical College \& Hospital, Jadavpur, Kolkata 700032, India.
}

Correspondence E-mail : waliza ansar@yahoo.co.in*, drskhasan2002@gmail.com

\begin{abstract}
Background: In the modern era of critical care management, sepsis remains a serious problem accounting for thousands of death per year with noteworthy morbidity and mortality. Sepsis results in multi-organ dysfunction secondary to culture-positive or negative infection. In diabetes mellitus (DM), the major problem is vurnerable infection or sometimes development of sepsis and septic shock. Researchers showed DM has reduced bacterial clearance as hyperglycemia decreases polymorphonuclear function and less production of inflammatory cytokines. Thus DM creates a comorbid condition in sepsis. The mechanism of the inter-twining of diabetes, infection and inflammatory response in sepsis is quite unclear.

Research methods: Our objective remains in clarifying the reliability of acute phase biomarkers as diagnostic tool (Procalcitonin; PCT and C-reactive protein; CRP) in diabetic patient in comparison to non-diabetic patients with sepsis. A total of 40 subjects, (20 patients had sepsis with DM, 20 patients had sepsis without DM) were enrolled. PCT, CRP, and other laboratory testing (WBC count, ESR, serum lactate, albumin) were done for all subjects at admission. Subjects were managed according to hospital protocol and followed up till remedy. Acute phase biomarker status was assessed based on their stratified concentration in groups.
\end{abstract}

Results: Compared with non-DM group, PCT and CRP in DM group were significantly high (all $\mathrm{P}<$ $0.05)$ and associated with bad outcome.

Conclusion: PCT level (> $40 \mathrm{ng} / \mathrm{mL}$; odds ratio $>1$ ) and CRP level (>100 mg/L; odds ratio $>1$ ) proved to be a reliable acute phase marker of sepsis patients with DM in Indian population.

Keywords: Sepsis, C-reactive protein, diabetes, biomarker, procalcitonin

\section{Introduction}

Early detection and timely management of sepsis is challenging for the critically ill patient. Sepsis and its allied complications remains the leading cause of mortality in adult admitted in the hospitals in India as well as worldwide. Delay in the diagnosis and management results in rapid progression to circulatory dysfunction, multiple organ failure and 
eventually death (Fleischmann et al., 2016; WHO 2018; Chatterjee et al., 2017). The deleterious, systemic inflammatory host response to infection by microbial agents (bacteria, fungi, virus and yeast) affecting all organs is defined as sepsis. It is complicated to diagnose patients with sepsis because there is a lack of specific clinical signs. Sepsis consolidates a spectrum of illness ranging from minor symptoms to even organ dysfunction (severe sepsis) and shock. Conventionally, diagnosis of sepsis was based on signs and symptoms of fever, leucocytosis, tachycardia, and tachypnea, supported by positive/negative bacterial culture (Levy et al., 2001; Singer et al., 2016). Frequently, septic patients present with chronic diseases like diabetes mellitus (DM). $\mathrm{DM}$, a multifaceted disease includes immune dysfunction, metabolic abnormalities, hyperglycemia with higher burden of cardiovascular and chronic kidney disease. Diabetes patients are unusually more vulnerable to infection (Wang et al., 2019; Shah and Hux, 2003) like severe otitis externa, rhinocerebral mucormycosis, emphysemmatous pyelonephritis, diabetic foot infection and emphysemmatous cholecystitis etc (Hine et al., 2017). Diabetic therapies and diabetes related immune abnormalities may influence the host response to infection as it has reduced bacterial clearance and thus outcome of sepsis also.

For laboratory diagnosis, prognosis and easy intervention in sepsis, the need for easyaccessible biomarkers at admission is inevitable. Currently, in our study we used acute phase reactants Procalcitonin (PCT) and C-reactive protein (CRP) as biomarkers to diagnose sepsis and predict outcomes. PCT is a 116 amino acid peptide precursor of the hormone calcitonin, the latter plays a role in calcium homeostasis (Snider et al, 1997). The specific uses of PCT as marker of systemic bacterial infections contribute towards its short half-life $(25-30 \mathrm{~h}$ in plasma) and spike concentration (within 6-12h) after infection in response to a pro-inflammatory stimulus. CRP, a sensitive inflammatory biomarker (Vashist et al., 2016) may be useful in determining sepsis severity and its progression. CRP an acute phase protein, belongs to a highly conserved pentraxins family, are characterized by its homo-pentameric structure and calciumdependent ligand-affinity for the phosphocholine (PC) (Tillet and Francis, 1930; Pepys and Baltz, 1983; Volanakis, 2001). The presence of $\mathrm{PC}$ in microbial cellular membranes enables CRP to recognize varied pathogenic antigens as well as binds to damaged and necrotic cells. In humans, the CRP concentration may rise to nearly 100 -fold or more during systemic inflammation from its normal low level (nearly $10 \mathrm{mg} / \mathrm{L}$ ) (Thompson et al, 1999; Pepys and Hirschfield, 2003). Thus CRP is probably the single most useful molecule for monitoring acute-phase reactions and in therapeutic decisions.

We conducted this study to evaluate the association and the diagnostic and predictive value of acute phase reactants, PCT and CRP in patients admitted to the hospital to test the hypothesis that higher concentrations of these acute phase biomarkers would be associated with sepsis patients having DM as compared to non-diabetic patients with sepsis.

\section{Materials and Methods}

\section{Study design}

It is a cross-sectional observational study, where the patients were admitted to ICU Unit, Fleming Hospital, Kolkata 700046 during the period June, 2018 to September, 2019. Medical records of 40 (out of total 43 screened patients; $93.023 \%)$ patients (45.5 \pm 18.5 years) were reviewed during their hospital stay as their infection was proved (sepsis group, culture positive) and in $3(6.97 \%)$ patients the source of infection was not identified (culture negative). One patient died during the study period (PCT=93.5 $\mathrm{ng} / \mathrm{ml}$; $C R P=45.6 \mathrm{mg} / \mathrm{L}$ ). Sepsis patients with DM (Group $\mathrm{l}=20$ individuals) and without DM (Group $\quad I=20$ individuals) were diagnosed according to the standard guidelines and treatment regime of the Indian Society of Critical care Medicine. Inclusion criteria includes diabetic foot, diabetic foot gangrene, perianal abscess, sternal abscess, malaria, pneumonia, urinary tract infection, emphysema gall bladder, pancreatitis, amoebic liver abscess and bronchopneumonia. Patients with history of malignancy or haematological disorders (like 
leukemia, lymphoma etc), any other chronic infective or inflammatory disorder (like rheumatoid arthritis, COPD, Crohn's disease, ulcerative colitis, connective tissue disorders, Graves disease), trauma or recent surgery, antitumor drug therapy, any kind of transplantation were excluded. We had recorded antimicrobial treatment history of enrolled patients.

Patient with DM for more than $5 \mathrm{yrs}$, with HBA1c level above $7 \%$ were included (Group I). Patient who never had no history or symptoms of diabetes in last 4 years and HBA1c level less than $5.5 \%$ and after admission their blood glucose level also recorded normal were included as control group (Group II).

\section{Data collection}

Observational medical data of the patients were noted for their demographics, initial diagnosis, length of hospital stay, and outcome (survived or expired) at the time of discharge from hospital. Blood samples were drawn from all subjects within $24 \mathrm{~h}$ of admission for complete haemogram, erythrocyte sedimentation rate (ESR), blood, urine and sputum culture. IgM antibodies against dengue and peripheral blood smear for malaria parasite were done when needed. The Institutional Human Ethical Committee had approved the study.

\section{Procalcitonin and C-reactive protein}

All samples (within $24 \mathrm{~h}$ of admission) were analyzed in the Department of Pathology and Biochemistry of the hospital. The PCT analysis was performed by Elecsys BRAHMS PCT electrochemiluminescence immunoassay on Cobas E-170 by Roche Diagnostics, Germany. Lower detection limit of the assay was 0.02 $\mathrm{ng} / \mathrm{mL}$ and upper detection limit was 100 $\mathrm{ng} / \mathrm{mL}$. Results were determined via a calibrator curve which was instrument-specific generated by 2-point calibration and a master curve provided via the reagent barcode. The analyzer automatically calculated the PCT concentration of each sample.

Serum CRP was measured by latex-enhanced nephelometry [Behring Nephelometer ADVIA 1800 chemistry system, Siemens] as per manufacturers' instructions. CRP present in the test sample will form an antigen-antibody complex with the latex particles. Quantitative CRP concentrations (done in triplicate, and the mean was used for analysis) are calculated by using a calibration curve. An automatic blank subtraction is performed. The assay range was $0.05-10 \mathrm{mg} / \mathrm{L}$. Samples with concentrations $>10 \mathrm{mg} / \mathrm{L}$ were re-calculated at higher dilutions.

\section{Statistical analysis}

The data were analyzed using Statistical Package for the Social Sciences version 22.0 (Armonk, NY: IBM Corp). The continuous variables with normal distribution were expressed as means \pm 2 standard deviation and were compared using the Student's $t$-test, whereas continuous variables with an asymmetric distribution were expressed as median. $P<0.05$ was considered statistically significant.

\section{Results}

A total of 40 enrolled patients admitted to the ICU of which 20 patients has sepsis with DM (Group I) and the rest has sepsis without DM (Group II=20 individuals). The median age of the study population was 44 years (27-63 years) with majority of study population was males $(67.5 \%)$. Duration of diabetes in each patient in Group I is variable. Nearly half of the study population had fever at presentation. Demographic variables (Patient's characteristics) of the study population including median age, percentage of survivors, male female ratio was summarized along with respective $p$ values in Table 1.

Table 1: Demographic variables of study population*

\begin{tabular}{l|c|c|}
\hline & $\begin{array}{c}\text { Sepsis with } \\
\text { DM } \\
(\mathrm{Gr} I, \mathrm{n}=20)\end{array}$ & $\begin{array}{c}\text { Sepsis } \\
\text { without DM } \\
(\mathrm{Gr} I \mathrm{I}, \mathrm{n}=20)\end{array}$ \\
\hline Male & $13(65 \%)$ & $14(70 \%)$ \\
\hline Female & $7(35 \%)$ & $6(30 \%)$ \\
\hline $\begin{array}{c}\text { Duration of } \\
\text { illness (days) }\end{array}$ & Acute & Acute \\
\hline Survivors & $19(95 \%)$ & $20(100 \%)$ \\
\hline Non-survivors & $1(5 \%)$ & $0(0 \%)$ \\
\hline $\begin{array}{c}\text { Median Age } \\
\text { (years) }\end{array}$ & 42 & 44.5 \\
*Data are expressed in number and \\
percentage. Age is expressed in median \\
values.
\end{tabular}


Some of the patient in the study cohort has comorbid conditions also. In $22.5 \%$ of patients, the primary diagnosis was cardiovascular disease, $15 \%$ suffered from diabetic foot or diabetic foot gangrene, $7.7 \%$ from different infections and $7.3 \%$ from peri-anal abscess or sterna abscess disease, while $12.5 \%$ had pneumonia or bronchiolitis, $15 \%$ had gastrointestinal disorders, $5 \%$ urinary tract infections and $15 \%$ suffered from miscellaneous causes. Out of the 40 patients, $85.2 \%$ were admitted through emergency, 4.1 $\%$ from operation rooms and $10.7 \%$ from other wards. All patients had blood culture within $24 \mathrm{~h}$ of admission and were reported positive in 37 patients $(92.5 \%)$. The outcome of 40 admitted patients were 39 survivors $(97.5 \%)$ and one non-survivor (2.5\%).

Table 2: Laboratory investigation of patients*

\begin{tabular}{|l|c|c|c|}
\hline & $\begin{array}{c}\text { Sepsis } \\
\text { with DM } \\
(\mathrm{Gr} I, \\
\mathrm{n}=20)\end{array}$ & $\begin{array}{c}\text { Sepsis } \\
\text { without } \\
\mathrm{DM} \\
(\mathrm{Gr} I \mathrm{I},\end{array}$ & $\begin{array}{c}\mathrm{p} \text { value } \\
(\mathrm{p}<0.05)\end{array}$ \\
\hline Age(years) & $27-63$ & $27-63$ & 0.37 \\
Range (Median) & $(42)$ & $(44.5)$ & \\
\hline Hb (g/dL) & $9.8-12.5$ & $10.1-$ & 0.28 \\
& & 12.3 & \\
\hline WBC(x10 $/ \mathrm{L})$ & $19-43$ & $14-26$ & 0.00001 \\
\hline CRP (Median ) & $67-$ & $21-193$ & 0.00001 \\
(mg/L) & $391(228)$ & $(133)$ & \\
\hline PCT(Median ) & $1.1-114$ & $0.8-54$ & 0.0031 \\
(ng/mL) & $(43)$ & $(23.5)$ & \\
\hline Serum lactate & $4.0-12.1$ & $3.8-8.2$ & 0.00001 \\
(mmol/L) & $(9.13)$ & $(6.16)$ & \\
\hline ESR & $14-55$ & $10-42$ & 0.084 \\
& $(33.3)$ & $(30.35)$ & \\
\hline Serum albumin & $1.8-3.2$ & $2.9-3.7$ & 0.00001 \\
(g/dL) & $(2.78)$ & $(3.27)$ & \\
\hline Urea (mg/dL) & $27.3-$ & $21.9-$ & 0.00014 \\
& 126.1 & 62.7 & \\
\hline Creatinine(mg/dL) & $0.9-1.6$ & $0.8-2.1$ & 0.1052 \\
& $(1.37)$ & $(1.47)$ & \\
\hline
\end{tabular}

*Values are expressed in range. $p$ value at 0.05 level is taken as significant. Some values (in parenthesis) are expressed in median value (lower quartile-upper quartile).WBC=White blood Cell, $\mathrm{Hb}=$ Hemoglobin, $\mathrm{CRP}=\mathrm{C}$ reactive protein, $\mathrm{PCT}=$ Procalcitonin, Sedimentation Rate.

Correlation between the clinical parameters of Group I and Group II is shown in Table 2. No significant differences were found for age, hemoglobin concentration, ESR and creatinine among the groups $(p<0.05)$. Group I patients had higher WBC count, higher levels of CRP and PCT, serum lactate and Urea than Group II (Table 2). So there is significant differences between WBC count, CRP PCT and serum lactate concentration and Urea among the groups $(p<0.05)$. CRP level was 2.03-3.2 fold higher in Group I than Group II.PCT level in Group I is $1.38-2.11$ fold more than Group II. Comparable level of serum albumin and creatinine was observed in both groups (Table 2). Acute phase biomarker (PCT and CRP) along with serum lactate (another sepsis biomarker) (Singer et al., 2016; Shankar-Hari et al., 2016) were significantly higher in Group I than Group II (2.78 [1.8-3.2] vs. 3.27 [2.9-3.7] $\mathrm{mmol} / \mathrm{L} ; \mathrm{p}<0.00001$ ) (Table 2). Random Blood Sugar (RBS), $\mathrm{HbA}_{1} \mathrm{C}$ (Glycated Hemoglobin) and CBG (Capillary Blood Glucose) was significantly higher in Group I diabetic patients(Table 3). The level of RBS, $\mathrm{Hb} \mathrm{A}_{1} \mathrm{C}$ and $C B G$ were within the normal limit in Group II patients.

Table 3: Sugar profile of patients*

\begin{tabular}{|c|c|c|c|}
\hline & $\begin{array}{c}\text { Sepsis } \\
\text { with DM } \\
\text { (Gr I, } \\
\mathrm{n}=20) \\
\text { Range } \\
\text { (median) }\end{array}$ & $\begin{array}{c}\text { Sepsis } \\
\text { without DM } \\
\text { (Gr II, } \\
\mathrm{n}=20) \\
\text { Range } \\
\text { (median) }\end{array}$ & $\begin{array}{c}p \text { value }(p \\
<0.05)\end{array}$ \\
\hline $\begin{array}{l}\text { RBS } \\
(\mathrm{mg} / \mathrm{dl})\end{array}$ & $\begin{array}{c}187- \\
391(311.5)\end{array}$ & $\begin{array}{c}124- \\
209(163)\end{array}$ & $<0.00001$ \\
\hline $\begin{array}{l}\mathrm{HbA}_{1} \mathrm{C} \\
(\%)\end{array}$ & $\begin{array}{c}8.6-11.4 \\
(9.9)\end{array}$ & $\begin{array}{c}5.6-6.4 \\
(6.1)\end{array}$ & $<0.00001$ \\
\hline $\begin{array}{l}\text { CBG } \\
(\mathrm{mg} / \mathrm{dl})\end{array}$ & $\begin{array}{c}202- \\
426(346.5)\end{array}$ & $\begin{array}{c}97-186 \\
(147)\end{array}$ & $<0.00001$ \\
\hline
\end{tabular}

*RBS=Random Blood Sugar; $\mathrm{HbA}_{1} \mathrm{C}=$ Glycated Hemoglobin ;CBG= Capillary Blood Glucose

To determine the range of variation in patients, PCT and CRP values were graded along their increasing concentration in Table 4 and Table 5. PCT level $>2 \mathrm{ng} / \mathrm{ml}$ was observed in 36 $(90 \%)$ patients and more than $100 \mathrm{ng} / \mathrm{ml}$ in 3 patients (7.5\%) in Group I. No patients had PCT level $>100 \mathrm{ng} / \mathrm{ml}$ in Group II (Table 4). CRP level $>100 \mathrm{mg} / \mathrm{L}$ was observed in 32 $(80 \%)$ patients where 8 patients of Group I had CRP level $>240 \mathrm{mg} / \mathrm{L}$. No patients had CRP level $>240 \mathrm{mg} / \mathrm{L}$ in Group II (Table 5). Very high concentration of PCT and CRP was observed in Group I. 
Table 4: Concentration of procalcitonin $(\mathrm{ng} / \mathrm{ml})$ in patients

\begin{tabular}{|l|c|c|c|}
\hline $\begin{array}{l}\text { PCT } \\
(\mathrm{ng} / \mathrm{mL})\end{array}$ & $\begin{array}{c}\text { Sepsis } \\
\text { with DM } \\
(\mathrm{Gr} I, \\
\mathrm{n}=20)\end{array}$ & $\begin{array}{c}\text { Sepsis } \\
\text { without DM } \\
(\mathrm{Gr} I \mathrm{II} \\
\mathrm{n}=20)\end{array}$ & $\begin{array}{c}\mathrm{p} \text { value }(\mathrm{p} \\
<0.05)\end{array}$ \\
\hline Upto 10 & $\begin{array}{c}2.5 \\
(4 ; 20 \%)\end{array}$ & $\begin{array}{c}2 \\
(4 ; 20 \%)\end{array}$ & 0.3954 \\
\hline $10-40$ & $\begin{array}{c}26.5 \\
(6 ; 30 \%)\end{array}$ & $\begin{array}{c}23.5 \\
(14 ; 70 \%)\end{array}$ & 0.002675 \\
\hline $40-100$ & $\begin{array}{c}69 \\
(7 ; 35 \%)\end{array}$ & $\begin{array}{c}48.5 \\
(2 ; 10 \%)\end{array}$ & 0.000106 \\
\hline 100 & $\begin{array}{c}110 \\
(3 ; 15 \%)\end{array}$ & $\begin{array}{c}0 \\
(0)\end{array}$ & $<0.00001$ \\
\hline
\end{tabular}

*Values are expressed in median (number of patients and percentage in parenthesis). $p$ value at 0.05 level is taken as significant. Concentration of Procalcitonin from $>10 \mathrm{ng} / \mathrm{mL}$ to $>100 \mathrm{ng} / \mathrm{mL}$ in 2 groups were noted.

Table 5: Concentration of CRP (mg/l) in patients

\begin{tabular}{|c|c|c|c|}
\hline $\begin{array}{c}\text { CRP } \\
\text { (mg/L) } \\
\text { Median } \\
\text { (No. of } \\
\text { patient;\%) }\end{array}$ & $\begin{array}{c}\text { Sepsis } \\
\text { with DM } \\
(\mathrm{Gr} I, \\
\mathrm{n}=20)\end{array}$ & $\begin{array}{c}\text { Sepsis } \\
\text { without } \\
\text { DM } \\
(\mathrm{Gr} I \mathrm{I} \\
\mathrm{n}=20)\end{array}$ & $\begin{array}{c}p \text { value ( } p \\
<0.05)\end{array}$ \\
\hline $20-60$ & $0(0)$ & $\begin{array}{c}33.5 \\
(4 ; 20 \%)\end{array}$ & 0.00134 \\
\hline $61-120$ & $\begin{array}{c}84 \\
(3 ; 15 \%)\end{array}$ & $\begin{array}{c}72 \\
(3 ; 15 \%)\end{array}$ & 0.3933 \\
\hline $121-180$ & $\begin{array}{c}165 \\
(3 ; 15 \%)\end{array}$ & $\begin{array}{c}150.5 \\
(12 ; 60 \\
\%)\end{array}$ & 0.000019 \\
\hline $181-240$ & $\begin{array}{c}218.5 \\
(6 ; 30 \%)\end{array}$ & $\begin{array}{c}193 \\
(1 ; 5 \%)\end{array}$ & 0.000382 \\
\hline 240 & $\begin{array}{c}333 \\
(8 ; 40 \%)\end{array}$ & $\begin{array}{c}0 \\
(0)\end{array}$ & $<0.00001$ \\
\hline
\end{tabular}

*Values are expressed in median (number of patients and percentage in parenthesis). $p$ value at 0.05 level is taken as significant. Concentration of CRP from $20 \mathrm{mg} / \mathrm{L}$ to $>240 \mathrm{mg} / \mathrm{L}$ in 2 groups were noted.

\section{Discussion}

Sepsis is the most common cause of noncoronary death in ICU with massive epidemiological burden. It is a progressively common cause of mortality and morbidity especially in critically ill patients, elderly and immune-compromised individuals. According to Sepsis-3 guidelines, sepsis was defined as life-threatening organ dysfunction caused by a dysregulated host response to infection (Levy et al., 2003; Singer et al., 2016; Shankar-Hari, et al., 2016; Seymour et al., 2016). Sepsis refers to the systemic response to infection by different microbes such as bacteria, yeast, parasite and fungi where the patient usually develops high fever, leukocytosis, tachycardia and tachypnea etc. Bacteria causes the most common pathogenic invasions (Feldmann and Geistbert, 2011; Calrk et al., 2004; Paessler and Walker, 2013). Sepsis connected with multiple organ dysfunction syndrome (MODS) or hypotension is known as septic shock (Reinhart et al., 2010). The signs and symptoms of sepsis are mostly variable and are influenced by pathogen burden, virulence factor, host susceptibility and the portal of entry. Respiratory tract, gastrointestinal tract and genitourinary infections are the primary infection sites.

It has been anticipated that diabetes will affect nearly 57.2 million people by 2025 in India based on World Health Organization (WHO) report (King et al., 1998). Thus the occurrence of sepsis in DM patients has become more recurrent, as it is well recognized that the cells partaking in the innate and adaptive immune responses in diabetic patients have immunecompromised function with chronic low grade inflammation (Wellen et al., 2005).

Early evaluative diagnosis and prompt antimicrobial therapy are the aspects of early management of sepsis. The major diagnostic uncertainty remains even after thorough physical examination, scrutinizing the patient's history, chest X-ray, and different laboratory examinations. The overlapping signs and symptoms of bacterial and viral infections are also crucial. Thus, for definite differential diagnosis in these cases a more specific laboratory test is required. The scientific advancement in the clinical medicine equipped us to screen wide range of acute phase protein in sepsis development as relevant biomarkers to diagnose sepsis, deciding the treatment regime and management of antibiotics dosage (Sakr et al., 2008).

WBC count, CRP and interleukin-1 (IL-6) are conventional markers of sepsis used for diagnosis. The number of WBC increase during the acute phase responses (normal range: $4-10 \times 10^{9} / \mathrm{L}$ ).CRP tests are easy to perform at low cost with high analytical sensitivity (Brenner et al, 2014). In ICU sepsis patients, the optimization of the treatment delivered should not be restricted to clinical protocols and procedures, but also include risk management, performance, and early 
outcome (preferably in the first $24 \mathrm{~h}$ of patient's admission) predictions. CRP is most used biomarker of infection in ICU patients (Povoa et al., 2005; Lelubre et al., 2013). As the level of II-6 and TNF- increases in DM, so CRP concentration also increases (Boras et al., 2014; Szalai et al.,1998; Pickup et al., 2000).

Albumin is a negative acute phase marker (reference range $=3.5-5.5 \mathrm{~g} / \mathrm{dL}$ ), that is rapidly down-regulated by inflammatory signals (Hübner et al, 2016, Sang et al, 2015) as also evident from Table 2 . The serum lactate level is considered a sensitive sepsis and septic shock biomarker reflecting cell-based metabolism. The values of biomarker of infection may remain apparently normal in sepsis patients with depressed immune responses (Singer et al., 2016). Likewise, Filho et al conducted a retrospective cohort study including In 443 ICU patients admitted with severe sepsis or septic shock has the initial blood lactate level of more than 2.5 $\mathrm{mmol} / \mathrm{L}$ which best predict the 28-day mortality among these patients (Filho et al., 2016). In our study significant difference between lactate value was observed in Group I as compared to Group II (Table 2).

Compared to CRP, PCT has better prognostic and diagnostic value and employed in distinguishing bacterial and viral meningitis (Usama et al., 2011). Positive blood culture is a gold standard for confirmed bacteremia in identifying the causative agent for subsequent application in antimicrobial sensitivity, but the delayed bacterial culture report poses difficulty to clinicians for early sepsis diagnosis regime (Hine et al., 2017; Angus et al., 2001). In suspected cases, the traditional sepsis diagnosis includes blood, urine or bronchial fluid and/or cerebrospinal fluid (CSF) culture usually within 24 to 48 hours of admission. Sepsis diagnosis becomes difficult in negative culture report. Some laboratory investigations for bacterial infection diagnosis are either nonspecific or require longer estimation period.

PCT has better specificity for screening bacterial infections than other proinflammatory markers in sepsis diagnosis (Brechot et al., 2015). The PCT level rises rapidly than CRP levels and spikes within very short time. Appropriate therapeutics and timely respond by the patient causes the level of PCT returns to normal concentration quite faster than CRP (Standage and Wong, 2011). Raveendran 2019 reported that PCT and CRP are the common markers of sepsis. In general, as evident by various studies, PCT in combination with CRP would serve as a promising tool for understanding the cause, diagnosis, progression/ regression, prediction and outcome of sepsis management. PCT recently become a possible marker of interest in systemic inflammatory response to infection (Raveendran et al, 2019). Sharma et al. showed in their review PCT and CRP as important biomarker of neonatal sepsis with varied reported specificity and sensitivity. It was shown in a study of 75 neonates that PCT in combination with CRP and other laboratory tests for septic screening can help in better diagnosis of neonatal sepsis. Both CRP and and PCT showed a sensitivity of $88.90 \%$ and specificity of $80.30 \%$ for PCT and $89.40 \%$ for CRP (Sharma et al., 2017).

There was no noteworthy difference in medical history and demographic data, such as age, gender, and history of DM between the two groups (Table 1). Increased WBC count as inflammatory marker evident by $4.3-4.75$ fold increase in Group I. The level of blood PCT in healthy subjects is below the limit of clinical detection (normal range: $0.021-0.500$ $\mathrm{ng} / \mathrm{ml}$ ) (Dandona et al., 1994; Wang et al., 2019). The comparison of clinicopathological parameters between two groups (Table 2) illustrates the higher baseline inflammation index of Group II patients as compared with Group I. The level of PCT rises in response to a pro-inflammatory bacterial stimulus, and it is often grouped as an acute phase reactant (Long et al., 2012).PCT does not rise significantly in viral infection. In Group I patients, PCT level $>100 \mathrm{ng} / \mathrm{mL}$ was observed in $15 \%$ of the patients (Table 4). CRP level above $100 \mathrm{mg} / \mathrm{L}$ (indication of bacterial septicemia) was observed in $90 \%$ Group I patients. Increased PCT and CRP level was in agreement with other studies where these two acute phase biomarkers were related with severity with sepsis (Sierra et al., 2004; Davies, 2015). 
As DM increases the infection rate, so Group I patients with sepsis and DM had very high level of PCT and CRP.PCT, a marker of bacterial sepsis, also grades well with degree of sepsis (Meisner et al., 1999). It is also evident from Table 4. The blood levels of the three inflammatory markers tested (WBC, PCT and (RP) all exhibited noteworthy differences between Group I patients from Group II.

DM patients have elevated blood glucose levels (Table 3 ), which in the tissue surface layer will increase vulnerability to bacterial colonization and can eventually upregulate neutrophil adhesion and the expression of intercellular adhesion molecules, thereby downregulating neutrophil chemotaxis and their consequent antibacterial actions (Morigi et al.,1998).

The course of increasing concentrations of PCT and CRP (Table 4 and 5) in patients were shown by bad outcome of death of a patient with high PCT level $93.5 \mathrm{ng} / \mathrm{ml}$ and CRP of $45.6 \mathrm{mg} / \mathrm{L}$.It should be noted that all the enrolled patients had acute sepsis, as they were followed and observed for a period of 28 days; nobody had septic shock or severe sepsis. Patients with SIRS or sepsis were not individually analyzed, since distinction between non-infectious and infectious etiology of systemic inflammation is quite difficult, and this was not an objective of our study. Increase in the PCT levels of Group II patients with DM may be associated with insulin resistance and other metabolic syndromes (Becker et al., 2004).

This study has some limitations. It is a study carried out on a small population in a single hospital, which limits the extent of the results, so the study remains observational. Positive microbial culture results may be also be

\section{References}

Angus D.C., Linde-Zwirble W.T., Lidicker J., Clermont G., Carcillo J., Pinsky M.R. (2001). Epidemology of severe sepsis in the United States. Analysis of incidence, outcome and associated cost of care. Crit Care Med., 29, 1303-10.

Becker K.L., Nylen E.S., White J.C., Muller B., Snider R.H., Jr. (2004). Clinical review 167: caused by contamination and negative results do not eliminate sepsis. Since most common laboratory and clinical parameters lack specificity and sensitivity, other tests are required to give a glance of early marker of the infection that causes the inflammatory response to permit early diagnosis and for the employment of specific treatment.

PCT and CRP are reliable marker in Group I than ESR and WBC count. PCT is also reported as an interesting biomarker to estimate the prognosis of severe systemic inflammatory response and sepsis (Gramm et al., 1995; Oberhoffer et al., 1996; Meisner et al., 1999). PCT and CRP along with other laboratory parameters (WBC count, serum lactate) may turn out to be the most promising sepsis markers, capable of balancing clinical symptoms and routine laboratory investigations suggestive of severe infection. In a systematic review in 2018, PCT performs better than CRP in diagnostic accuracy of predicting sepsis (Tan et al, 2018; Davies, 2015). The role of PCT and CRP in prognosis, prediction and diagnostic values in sepsis patients with DM in Indian population has not been studied well.

\section{Conflicts of Interest}

The authors declare that there are no conflicts of interest regarding the publication of this work.

\section{Acknowledgment}

We must thank Dr. lqbal Nayyer for his scientific inputs. We acknowledge the doctors, technical staffs and patients of Fleming hospital for this study. We also acknowledge Behala College and K.P.C Medical College, Kolkata, India for their support.

Procalcitonin and the calcitonin gene family of peptides in inflammation, infection, and sepsis: A journey from calcitonin back to its precursors. J Clin Endocrinol Metab., 89, 1512-1525. doi: 10.1210/jc.2002-021444.

Boras E., Slevin M., Alexander M.Y., Aljohi A., Gilmore W., Ashworth J., Krupinski J., Potempa L.A., Al Abdulkareem I., Elobeid A., 
Matou-Nasri S. (2014). Monomeric C-reactive protein and Notch-3 co-operatively increase angiogenesis through PI3K signalling pathway. Cytokine., 69(2),165-79. doi: 10.1016/j.cyto.2014.05.027. Epub 2014 Jun 25.

Brechot N., Hekimian G., Chastre J., Luyt, C.E. (2015). Procalcitonin to guide antibiotic therapy in the ICU. Int $J$ Antimicrob Agents., 46, S19-S24. doi: 10.1016/j.ijantimicag.2015.10.012.

Brenner D.R., Scherer D., Muir K., Schildkraut J., Boffetta, P., Spitz M.R., Le Marchand L., Chan A.T., Goode EL., Ulrich C.M., Hung R.J. (2014). A review of the application of inflammatory biomarkers in epidemiologic cancer research. Cancer Epidemiol Biomarkers Prev., 23(9),1729-51. doi: 10.1158/1055-9965.EPI-14-0064. Epub 2014 Jun 24.

Calrk I.A., Alleva L.M., Mills A.C., Cowden W.B. (2004). Pathogen of malaria and clinically similar conditions. Clin Microbio Rev., 17(3),509-39.

Chatterjee S., Bhattacharya M., Todi S.K. (2017). Epidemiology of Adult-population Sepsis in India: A Single Center 5 Year Experience. Indian $J$ Crit Care Med. , 21(9),573-577. doi: 10.4103/ijccm.IJCCM_240_17.

Dandona P., Nix D., Wilson M.F., Aljada A., Love J., Assicot M., Bohuon C. (1994). "Procalcitonin increase after endotoxin injection in normal subjects". The Journal of Clinical Endocrinology and Metabolism., 79 (6), 1605-8. doi:10.1210/jc.79.6.1605. PMID 7989463.

Davies J. (2015).Procalcitonin. J Clin Pathol. , 68,675-679. doi: 10.1136/jclinpath-2014202807.

Feldmann H., Geistbert T.W. (2011). Ebola, hemorrhagic, fever. Lancet., 377(97768),84962.

Filho R.R., Rocha L.L., Corrêa T.D., Pessoa C.M., Colombo G., Assuncao M.S. (2016). Blood Lactate Levels Cutoff and Mortality Prediction in Sepsis-Time for a Reappraisal? a Retrospective Cohort Study. Shock., 46(5), 480-485.
Fleischmann. C., Scherag. A., Adhikari. N.K., Hartog C.S., Tsaganos T., Schlattmann P., Angus D.C., Reinhart K. (2016). International Forum of Acute Care Trialists. Assessment of Global Incidence and Mortality of Hospitaltreated Sepsis. Current Estimates and Limitations. Am J Respir Crit Care Med., 193(3), 259-72. doi: 10.1164/rccm.20150407810C.

Hine J.L., de Lusignan S., Burleigh D., Pathirannehelage S., McGovern A., Gatenby P., Jones S., Jiang D., Williams J., Elliot AJ., Smith GE., Brownrigg J., Hinchliffe R., Munro N. (2017). Association between glycaemic control and common infections in people with Type 2 diabetes: a cohort study. Diabet Med., 34(4), 551-557. doi: 10.1111/dme.13205. Epub 2016 Sep 22.

Hübner M., Mantziari S., Demartines N., Pralong F., Coti-Bertrand P., Schäfer M. (2016). Postoperative Albumin Drop Is a Marker for Surgical Stress and a Predictor for Clinical Outcome: A Pilot Study. Gastroenterol Res Pract., $8743187 . \quad$ doi: 10.1155/2016/8743187. Epub 2016 Jan 6.

King H., Aubert R.E., Herman W.H. (1998). Global burden of diabetes, 1995-2025: Prevalence, numerical estimates, and projections. Diabetes Care., 21,1414-31.

Lelubre C., Anselin S., Zouaoui Boudjeltia K., Biston P., Piagnerelli M. (2013). Interpretation of C-reactive protein concentrations in critically ill patients. Biomed Res Int., 124021. doi: 10.1155/2013/124021. Epub 2013 Oct 28.

Levy M.M., Fink M.P., Marshall J.C., Abraham E., Angus D., Cook D., Cohen J., Opal SM., Vincent J.L., Ramsay G. (2001). SCCM/ESICM/ACCP/ATS/SIS International Sepsis Definitions Conference. Intensive Care Med., 29, 530-538. doi: 10.1007/s00134-0031662-x.

Long S.S., Pickering LK., Prober C.G, eds. (2012). "Bacterial infections in the neonate". Principles and Practice of Pediatric Infectious Diseases (4th ed.). Elsevier., ISBN 9781437727029.

Meisner M., Tschaikowsky K., Palmaers T., Schmidt J. (1999). "Comparison of procalcitonin (PCT) and C-reactive protein 
(CRP) plasma concentrations at different SOFA scores during the course of sepsis and MODS". Critical Care., 3 (1), 45-50. doi:10.1186/cc306. PMC 29013. PMID 11056723.

Morigi M., Angioletti S., Imberti B., Donadelli R., Micheletti G., Figliuzzi M., Remuzzi A., Zoja C., Remuzzi G. (1998). Leukocyteendothelial interaction is augmented by high glucose concentrations and hyperglycemia in a NF-kB-dependent fashion. J Clin Invest., 101,1905-1915. doi: 10.1172/JCl656.

Oberhoffer M., Bögel D., Meier-Hellmann A., Vogelsang H., Reinhart K. (1996). Procalcitonin is higher in non-survivors during the clinical course of sepsis, severe sepsis and septic shock. Intensive Care Med., 22, A245.

Paessler S., Walker D.H. (2013). Pathogenesis of the viral hemorrhagic fever. Annu Rev Pathol., 8,411-40.

Pepys M.B., and Baltz M.L. (1983). Acute phase proteins with special reference to Creactive protein and related proteins (pentaxins) and serum amyloid A protein. Adv. Immunol., 34,141-212.

Pepys M.B. Hirschfield G.M. C-reactive protein: A critical update. J. Clin. Invest., 2003, 111, 1805-1812. doi:10.1172/JCI200318921.

Pickup J.C., Chusney G.D., Thomas S.M., Burt D. (2000).Plasma interleukin-6, tumour necrosis factor alpha and blood cytokine production in type 2 diabetes. Life Sci., 67(3), 291-300.

Póvoa P., Coelho L., Almeida E., Fernandes, A., Mealha R., Moreira P., Sabino H. (2005).Creactive protein as a marker of infection in critically ill patients. Clin Microbiol Infect.,11(2),101-8.

Raveendran A.V., Kumar A., Gangadharan S. (2019).Biomarkers and newer laboratory investigations in the diagnosis of sepsis. $J R$ Coll Physicians Edinb.,49(3),207-216. doi: 10.4997/JRCPE.2019.308.

Reinhart K., Bauer M., Reideman N.C., Hartog C.S. (2010). New approaches to sepsis: molecular diagnostics and biomarkers. $\mathrm{J} \mathrm{Cln}$ Microbiol., 25,609-34.
Sakr Y., Brgett U., Nacul F.E., Reinhart K., Brunkhorst F. (2008). Lipopolysaccharide binding protein in a surgical intensive care unit: a marker of sepsis? Crit Care Med., 36,2014-22.

Sang B.H., Bang J.Y., Song J.G., Hwang G.S. (2015). Hypoalbuminemia Within Two Postoperative Days Is an Independent Risk Factor for Acute Kidney Injury Following Living Donor Liver Transplantation: A Propensity Score Analysis of 998 Consecutive Patients. Crit Care Med., 43(12),2552-61. doi: 10.1097/CCM.0000000000001279.

Seymour C.W., Liu V.X., Iwashyna T.J., Brunkhorst F.M., Rea T.D., Scherag A., Rubenfeld G., Kahn J.M., Shankar-Hari M., Singer M., Deutschman C.S., Escobar G.J., Angus D.C. (2016). Assessment of Clinical Criteria for Sepsis: For the Third International Consensus Definitions for Sepsis and Septic Shock (Sepsis-3). JAMA., 23;315(8),762-74. doi: 10.1001/jama.2016.0288.

Shah B.R., Hux J.E. (2003).Quantifying the risk of infectious diseases for people with diabetes. Diabetes Care., 26, 510-513. doi: 10.2337/diacare.26.2.510.

Shankar-Hari M., Phillips G.S., Levy M.L., Seymour C.W., Liu V.X., Deutschman C.S., Angus D.C., Rubenfeld G.D., Singer M. (2016). Sepsis Definitions Task Force. Developing a New Definition and Assessing New Clinical Criteria for Septic Shock: For the Third International Consensus Definitions for Sepsis and Septic Shock (Sepsis-3). JAMA., 23, 315(8), 775-87. doi: 10.1001/jama.2016.0289.

Sharma D., Farahbakhsh N., Shastri S., Sharma P. (2018). Biomarkers for diagnosis of neonatal sepsis: a literature review. J Matern Fetal Neonatal Med., Jun;31(12),1646-1659. doi: 10.1080/14767058.2017.1322060.

Sierra R., Rello J., Bailen M.A., Benitez E., Gordillo A., Leon C., Pedraza S. (2004). Creactive protein used as an early indicator of infection in patients with systemic inflammatory response syndrome. Intens Care Med., 30,2038-2045. doi: 10.1007/s00134004-2434-y. 
Singer M., Deutschman C.S., Seymour C.W., Shankar-Hari M., Annane D., Bauer M., Bellomo R., Bernard G.R., Chiche J.D., Coopersmith C.M., Hotchkiss R.S., Levy M.M., Marshall J.C., Martin G.S., Opal S.M., Rubenfeld G.D., van der Poll T., Vincent J.L., Angus D.C. (2016). The third international consensus definitions for sepsis and septic shock (sepsis-3). JAMA., 23;315(8),801-10. doi: 10.1001/jama.2016.0287.

Snider R.H. Jr., Nylen E.S., Becker KL. (1997). Procalcitonin and its component peptides in systemic inflammation: immunochemical characterization. J Invest Med., 45,552-560.

Standage S.W., Wong H.R. (2011). Biomarkers for paediatric sepsis and septic shock. Expert Rev Anti-Infect Ther., 9(1),71-9.

Tan M., Lu Y., Jiang H., Zhang L. (2018). "The diagnostic accuracy of procalcitonin and $\mathrm{C}$ reactive protein for sepsis: A systematic review and meta-analysis". Journal of Cellular Biochemistry., $120 \quad$ (4), 5852-5859. doi:10.1002/jcb.27870. PMID 30417415.

Thompson D., Pepys M.B., Wood S.P. (1999) The physiological structure of human Creactive protein and its complex with phosphocholine. Structure, 7, 169-77. doi: 10.1016/S0969-2126(99)80023-9.

Tillet W.S., Francis T. (1930). Serological reactions in pneumonia with a non- protein somatic fraction of Pneumococcus. J Exp Med., 52(4):561-71. doi:10.1084/jem.52.4.561
Usama M., Nermin A., Ayman A., Sultan M.H. (2011). Serum procalcitonin in viral and bacterial meningitis. J Glob Infect Dis., 3:14-8.

Vashist S.K., Venkatesh A.G., Marion Schneider E., Beaudoin C., Luppa P.B., Luong J.H. (2016). Bioanalytical advances in assays for C-reactive protein. Biotechnol Adv., 34:272-290. doi: 10.1016/j.biotechadv.2015.12.010.

Volanakis J.E. (2001). Human C-reactive protein: expression structure and function. $\mathrm{Mol}$ Immunol., 38,189-97. doi:10.1016/S01615890(01)00042-6

Wang X., Sun Y., Shao X. (2019). Predictive value of procalcitonin for infection of patients with type-2 diabetes mellitus. Exp Ther Med., 18(1),722-728. doi:10.3892/etm.2019.7611.

Wellen K.E., Hotamisligil G.S. (2005). Inflammation, stress, and diabetes. J Clin Invest., 115, 1111-1119. doi: 10.1172/JCl25102.

World Health Organization. (2005). WHO Report on the burden of endemic health careassociated infection worldwide. 2017-11-21 15:11:22 2011.

World Health Organization. (WHO) (2018). https://www.who.int/news-room/factsheets/detail/sepsis 